\title{
Mineralogy and microstructure effects on the stiffness of activated slag treated alluvium
}

\author{
P. SARGENT* ${ }^{*}$ N. H. JABER† and M. ROUAINIA†
}

\begin{abstract}
Alkali-activated alumino-silicate-based industrial waste products have recently proven to be beneficial as low-carbon alternatives to ordinary Portland cement binders for strengthening soft soils. This paper examines the small-strain stiffness behaviour of a UK silty alluvial soil in its natural state and artificially cemented using sodium hydroxide-activated ground-granulated blast-furnace slag (GGBS). Undrained triaxial testing with bender element measurements revealed that the initial small strain shear stiffness $\left(G_{\max }\right)$, shear strength and hydraulic conductivity of the alluvium were all significantly enhanced after $28 \mathrm{~d}$ curing. Microstructural and mineralogical analyses were carried out on stabilised soil to understand the mechanisms better through which the enhanced engineering performances were achieved. Through hydration and pozzolanic reactions, a significant proportion of the clay minerals within the original soil had been converted into new cementitious hydrates. These were observed to infill pore spaces, coating soil and GGBS particle surfaces and increased interparticle bonding throughout the matrix of the material. The outcomes from this study have the potential to contribute towards improving current practices for modelling cemented soils and ultimately making geotechnical designs involving deep soil mixing less conservative.
\end{abstract}

\section{KEYWORDS: microscopy; mineralogy; soil stabilisation}

Published with permission by the ICE under the CC-BY 4.0 license. (http://creativecommons.org/licenses/by/4.0/)

\section{INTRODUCTION}

Soft alluvial soils possess low bearing capacities and high compressibilities, presenting difficulties in the design and construction of foundations. Rather than using expensive conventional piling methods, an increasingly popular alternative is deep soil mixing (DSM) ground improvement. The most commonly used DSM binder is ordinary Portland cement (CEM-I), due to its high strength and durability performance (Horpibulsuk et al., 2010; Kang et al., 2017; Hancock, 2019; Zhu et al., 2019). However, its continued use is environmentally unsustainable as its production accounts for $\sim 7 \%$ of global carbon dioxide $\left(\mathrm{CO}_{2}\right)$ emissions (Pourakbar et al., 2015; Sargent et al., 2016). Hence, efforts are now being made to focus on the development of low carbon binders, with an emphasis on improved circular economy by utilising industrial waste products (IWMs).

There have been many unconfined compressive strength (UCS)-based laboratory studies undertaken on soils stabilised with IWMs including GGBS, pulverised fly ash (PFA) and biomass ash as partial replacements to CEM-I (Al-Tabbaa \& Evans, 1998; Ahnberg, 2007; Horpibulsuk et al., 2010; Ghadir \& Ranjbar, 2018). While the results from these studies are positive, more effort is needed on the total replacement of CEM-I if the construction sector intends to make a valuable and timely contribution towards reducing global carbon dioxide emissions. Using GGBS and type-F

Manuscript received 5 November 2019; first decision 18 March 2020; accepted 19 March 2020.

Published online at www.geotechniqueletters.com on 14 April 2020.

*School of Computing, Engineering and Digital Technologies, Teesside University, Middlesbrough, UK

(Orcid:0000-0001-5789-1076).

†Civil Engineering Department, College of Engineering, University of Kerbala, Kerbala, Iraq.

tSchool of Engineering, Newcastle University, Newcastle upon Tyne, UK (Orcid:0000-0001-5623-4314).
PFA for soil stabilisation requires alkali activation (Haha et al., 2011). Sargent et al. (2013) revealed that using sodium hydroxide-sodium silicate $\left(\mathrm{NaOH}-\mathrm{NaSiO}_{3}\right)$ activated GGBS-based binders to stabilise an artificial alluvium (silty sandy clay) produced UCS of $6 \mathrm{MPa}$ after $28 \mathrm{~d}$ and durability performances exceeding those of CEM-I stabilised mixtures (3 MPa after 28 d). Cristelo et al. (2013) performed a similar study, which focused on the use of sodium hydroxide at various molar concentrations (10-15 molar) to activate type F PFA for stabilising a Portuguese sandy clay. The $28 \mathrm{~d}$ UCS values recorded in their study ranged between 2 and $12 \mathrm{MPa}$, which continued to increase up to approximately $45 \mathrm{MPa}$ after $365 \mathrm{~d}$. More recently, Mohammadinia et al. (2019) investigated the use of sodium hydroxide-sodium silicate activated type F PFA and GGBS, rather than CEM-I for stabilising loose sands (sourced from Melbourne, Australia) through DSM. UCS values for alkali-activated PFA-GGBS mixtures surpassed FHWA criterion and were at least comparable for CEM-I mixtures after curing periods of 7,14 and $28 \mathrm{~d}$ and for dosages of 16 and 25\%. Interestingly, Mohammadinia et al. (2019) established that using a higher proportion of GGBS in the PFA-GGBS binder resulted in higher $28 \mathrm{~d}$ UCS values being achieved $(15 \mathrm{MPa})$ that surpassed the performance of CEM-I mixtures (9 MPa).

With the prospect of DSM being increasingly used to form deep foundations, further investigation is recommended regarding the small-strain behaviour of cemented soils (Bonal et al., 2012). Further to disagreement between studies undertaken by Cuccovillo \& Coop (1997) on calcarenite, Yun \& Santamarina (2005) on artificially cemented sand and Hird \& Chan (2008) on artificially cemented clay, Trhlikova et al. (2012) investigated the structure and $G_{\max }$ of a CEM-I stabilised kaolin clay. They established that post-yield, $G$ increased with mean effective stress $\left(p^{\prime}\right)$ when compression (structure degradation) rates were low (and vice versa). However, Trhlikova et al. (2012) were unable to capture pre-yielding behaviour characterised by constant $G$ 
with increasing $p^{\prime}$, which is typical of high-strength cemented soils. Rios et al. (2014) investigated the small-strain behaviour of artificially CEM-I-treated Porto sand using triaxial apparatus. While failure envelopes were successfully identified for the material in multiple stress planes, Rios et al. (2014) were unable to capture strain behaviour sub-0.001\% shear strain $\left(\varepsilon_{\mathrm{q}}\right)$ due to the resolution of strain measurement apparatus used. Rios et al. (2017) performed another triaxial-based study on a silty sand stabilised with alkali-activated fly ash, to assess their small-to-large strain behaviour after 28 and $90 \mathrm{~d}$ curing. They observed that the strength development behaviour of alkali-activated PFA-stabilised soil contrasted with cement-stabilised counterparts, whereby peak strengths for the latter were recorded after $28 \mathrm{~d}$ whereas strength development continued for the former - doubling in initial elastic stiffness $\left(E_{0}\right)$ from approximately $2.9 \mathrm{GPa}$ after $28 \mathrm{~d}$ to $6.3 \mathrm{GPa}$ after $90 \mathrm{~d}$. Ultrasonic measurements used by Rios et al. (2017) to measure $G$ also revealed that Poisson's ratio of samples slightly decreased during the initial days of curing, which then increased after $7 \mathrm{~d}$. This suggested that curing only has an effect on sample strength and stiffness after $7 \mathrm{~d}$ curing, which is contrary to the behaviour of soil-cement mixtures.

This paper presents results from an investigation into the degradation of $G_{\max }$ for a soft alluvium stabilised with a new sodium hydroxide-activated GGBS binder after $28 \mathrm{~d}$ curing and the resulting mineralogical and microstructural modifications.

\section{MATERIALS AND TESTING METHODOLOGIES Sample preparation}

The alluvium was obtained from Lanton (Northumberland, UK), which has previously been classified in terms of its geotechnical index properties by Sargent et al. (2016). According to the Unified Soil Classification System (USCS), the alluvium may be characterised as an inorganic silty clay of low-to-medium plasticity (CL). In terms of particle size grading, the soil was found to have a uniformity coefficient of 4.71 and coefficient of curvature of 0.90 . To ensure homogeneous stabilised samples were produced in the laboratory, the soil was oven-dried at $100^{\circ} \mathrm{C}$ for $24 \mathrm{~h}$ and milled down to a fine powder $(<40 \mu \mathrm{m})$. Further to Sargent et al. (2016), a GGBS-sodium hydroxide dosage of $7 \cdot 5 \%$ by dry weight (5\% GGBS, $2 \cdot 5 \%$ sodium hydroxide) was added to the soil and mixed mechanically for $5 \mathrm{~min}$. The sodium hydroxide used was in pellet form and had a molarity of $39.997 \mathrm{~g} / \mathrm{mol}$. Deionised water was then added to achieve a moisture content of $25 \%$ (based on the alluvium's in situ moisture content) and mixed for a further $5 \mathrm{~min}$.

According to BS 1377 (BSI, 1990), cylindrical samples $140 \mathrm{~mm}$ long $\times 70 \mathrm{~mm}$ diameter were prepared for triaxial testing. In accordance with Cristelo et al. (2013), Sargent et al. (2016) and Rios et al. (2017), stabilised samples were manually compacted in three layers into polyvinyl chloride moulds to achieve a bulk density of $1.9 \mathrm{Mg} / \mathrm{m}^{3}$ and then wax-sealed for $28 \mathrm{~d}$ curing in a temperature and humiditycontrolled room $\left(20^{\circ} \mathrm{C}, 55 \%\right.$ relative humidity).

\section{Triaxial testing}

Isotropically consolidated undrained (ICU) and unconsolidated undrained (UU) triaxial tests were performed on samples according to BS 1377-8 (BSI, 1990). For ICU tests, sample saturation was confirmed by using the Skempton pore-pressure coefficient ' $B$ ' test. $B$ values measured for samples ranged between 0.95 and 0.98 - indicating full saturation had been achieved. During ICU tests, coefficients of vertical permeability $\left(k_{\mathrm{v}}\right)$ were also measured, whereby at $22^{\circ} \mathrm{C} k_{\mathrm{v}}$ values for the untreated and $28 \mathrm{~d}$ stabilised alluvium were $1.41 \times 10^{-8}$ and $4.02 \times 10^{-9} \mathrm{~m} / \mathrm{s}$, respectively. For sample compression, a constant strain rate of $0 \cdot 001 \mathrm{~mm} / \mathrm{min}$ was adopted.

\section{Small-strain measurements}

For taking shear stiffness measurements of the untreated alluvium at the end of isotropic consolidation and during compression over small to large $\varepsilon_{\mathrm{q}}$, bender elements (installed within the triaxial top cap and base pedestal) were gently pressed into the sample ends by $3-5 \mathrm{~mm}$. Whereas for $28 \mathrm{~d}$ cured GGBS-sodium hydroxide stabilised alluvium samples, $5 \mathrm{~mm}$ deep slots were manually created by using a Stanley knife. The material removed from the slots was then re-wetted and used as a coupling agent to infill any gaps between the bender element and the sample, ensuring successful transmission of S-waves. To ensure high-quality $\mathrm{S}$-wave signals, at least three $\mathrm{S}$-wave wavelengths were required to pass through samples. Based on Sargent et al. (2016), estimations were made for shear wave velocity $\left(V_{\mathrm{s}}\right)$ to select a frequency of $20 \mathrm{kHz}$ for generating S-waves. This was sufficiently high to compensate for the near-field effect (Cai et al., 2015). According to Sargent (2015), the time-domain technique was adopted for determining $V_{\mathrm{s}}$ and ultimately $G_{\max }$.

\section{Mineralogy and microstructure}

To investigate the microstructure of the alluvium before and after stabilisation, scanning electron microscopy (SEM) and point elemental energy-dispersive X-ray (EDX) analyses were carried out by using a Philips XL30 ESEM-FEG. Qualitative X-ray diffraction (XRD) analyses were also undertaken to study the mineralogy of the untreated and GGBS-sodium hydroxide-treated alluvium. The equipment used was a PANalytical X'Pert Pro MPD, powered by a Philips PW3040/60 X-ray generator and fitted with an $\mathrm{X}$ 'celerator detector. Samples were subjected to $\mathrm{Cu}-\mathrm{K} \alpha$ X-rays, which had a wavelength of $1 \cdot 5418 \AA$. Mineral phase identification was enabled through the use of the PANalytical High Score Plus software and the ICDD Powder Diffraction File 2 Database, sets 1-49 (ICDD, 1999).

\section{RESULTS AND DISCUSSION \\ Strength and stiffness}

Table 1 summarises the triaxial conditions, sample dimensions and bender element measurements for untreated and treated samples. During shearing, $V_{\mathrm{s}}$ decreased with $\varepsilon_{\mathrm{q}}$ particularly beyond $0.5 \%$. This is likely due to strain localisation and dilation on yielding.

Figure 1 shows the deviatoric stress $(q)-\varepsilon_{\mathrm{q}}$ behaviour of ICU and UU tests. Peak $q$ ranged between 2000 and $2580 \mathrm{kPa}$ for ICU tests and $2430-2980 \mathrm{kPa}$ for UU tests. Stabilised samples chiefly exhibited peak strength with post-yield softening behaviour akin to heavily overconsolidated soils and rocks. However, sample UU_5_600 showed hardening behaviour similar to normally consolidated soils. This can be attributed to the confining stress being greater than the quasi-preconsolidation stress (Ahnberg, 2007) or the apparent overconsolidation ratio linked to the Hvorslev equivalent pressure (Trhlikova et al., 2012). Figure 2 shows the $G_{\max }$ degradation curves for all ICU and UU tests.

From Fig. 2(a), stabilisation and $p^{\prime}$ influence $G_{\max }$ of ICU samples, whereby higher $p^{\prime}$ result in higher $G_{\max }$. This is inconsistent with Hird \& Chan (2008) and Dvorkin et al. 
Table 1. Summary of sample testing conditions and $G_{\max }$ measurements taken at the start of compression

\begin{tabular}{c|l|l|l|l|l|l|l}
\hline Material & $\begin{array}{l}\text { Triaxial } \\
\text { condition }\end{array}$ & $p_{0}^{\prime}: \mathrm{kPa}$ & $\begin{array}{l}\text { Sample length: } \\
\mathrm{mm}\end{array}$ & $\begin{array}{l}\text { Sample } \\
\text { diameter: } \mathrm{mm}\end{array}$ & $\rho: \mathrm{Mg} / \mathrm{m}^{3}$ & $V_{\mathrm{s}}: \mathrm{m} / \mathrm{s}$ & $G_{\max }: \mathrm{MPa}$ \\
\hline $\begin{array}{c}\text { Untreated Lanton } \\
\text { alluvium }\end{array}$ & ICU & 50 & $140 \cdot 12$ & $71 \cdot 42$ & $2 \cdot 05$ & $211 \cdot 02$ & $89 \cdot 06$ \\
$\begin{array}{c}28 \text { d cured 7.5\% } \\
\begin{array}{l}\text { GGBS-sodium } \\
\text { hydroxide-treated } \\
\text { Lanton alluvium }\end{array}\end{array}$ & $\mathrm{ICU}$ & $\begin{array}{c}50,200, \\
400,600\end{array}$ & $139 \cdot 83-141 \cdot 30$ & $73 \cdot 22-73 \cdot 66$ & $1 \cdot 98-2 \cdot 02$ & $743 \cdot 50-980 \cdot 43$ & $1052 \cdot 80-1877 \cdot 45$ \\
\hline
\end{tabular}

NB: sample ID notation 'ICU/UU_sample no._p $p_{0}^{\prime}$ condition'.

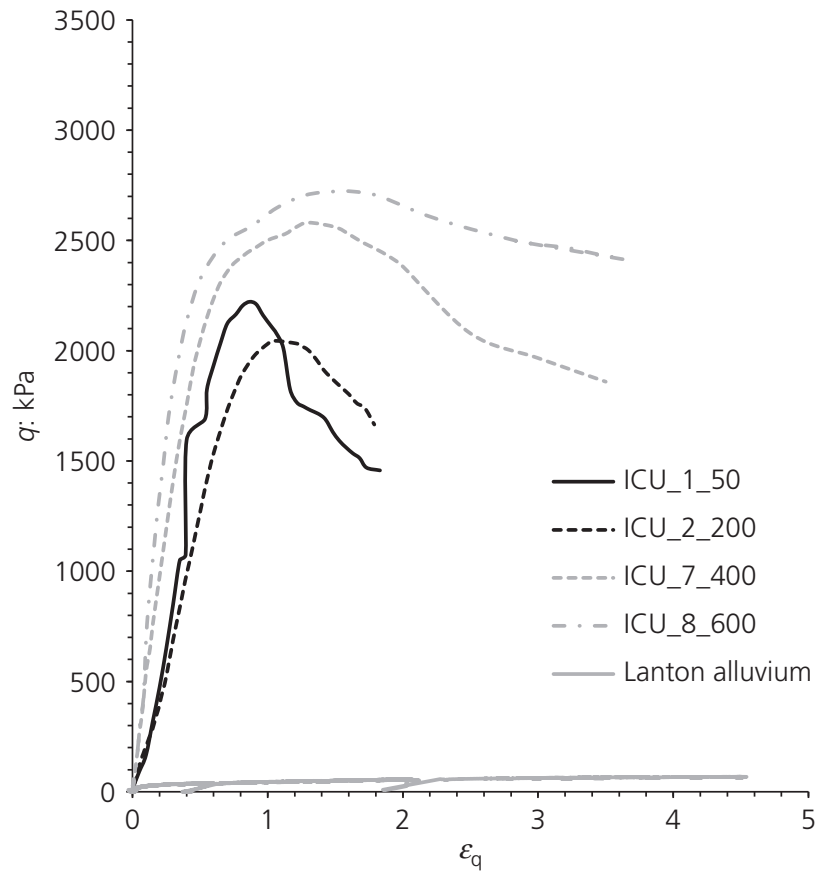

(a)

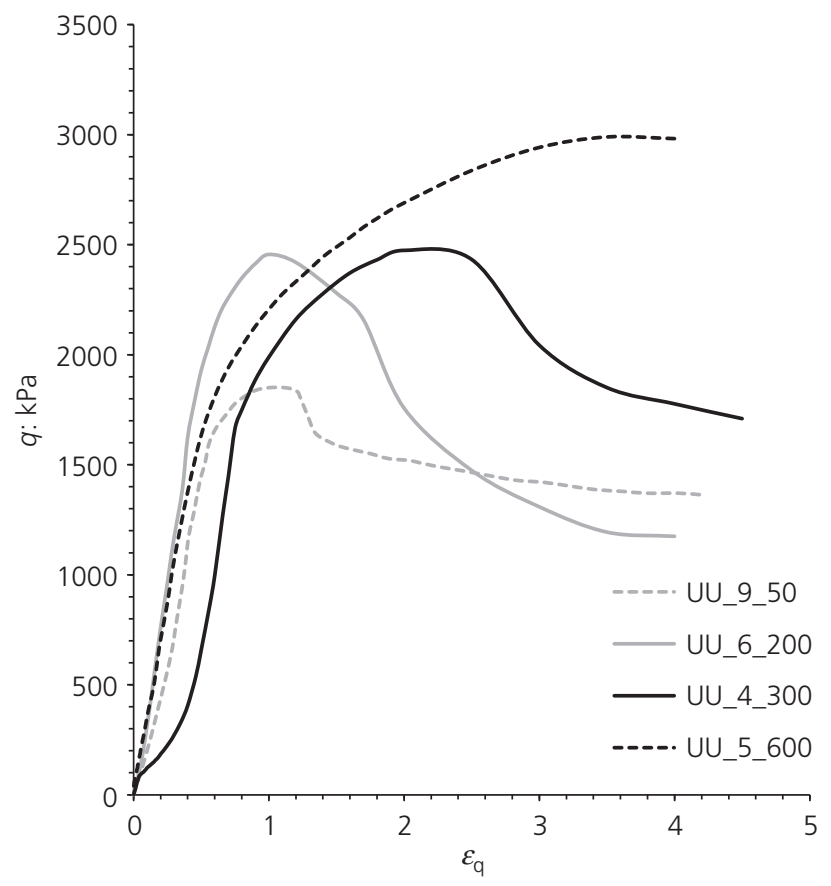

(b)

Fig. 1. Deviatoric stress-shear strain response of the untreated and $28 \mathrm{~d}$ cured GGBS-sodium hydroxide-treated Lanton alluvium under (a) ICU and (b) UU triaxial testing conditions

(1991). The relationship between $p^{\prime}$ and $G_{\max }$ is dependent on the degree of cementation within the stabilised soil's matrix. For stabilised soils whose matrices are strongly cemented, increasing the $p_{0}^{\prime}$ condition is not anticipated to break down the cementitious bonds, as observed by Consoli et al. (2009). Conversely, for stabilised soil matrices with weaker levels of cementation, increasing $p^{\prime}$ will more likely cause cementitious bonds to collapse - resulting in lower values of $G_{\max }$. Figure 2(b) demonstrates the effect of $p^{\prime}$ on $G_{\max }$ is less significant for UU tests. This corroborates typical behaviour for untreated soils, demonstrating the effect of total against effective stress behaviour. From all the tests undertaken, stabilisation and $28 \mathrm{~d}$ curing increased $G_{\max }$ of the untreated alluvium by factors of 11-20, achieving 1052-1877 MPa.

Figure 2 shows that the onset of $G_{\max }$ degradation for stabilised ICU and UU samples chiefly occurred at $\varepsilon_{\mathrm{q}}=1 \%$. This is a significant improvement compared with the untreated alluvium, where $G_{\max }$ degradation started at $\varepsilon_{\mathrm{q}}=$ $0.008 \%$. The $G_{\max }$ degradation rate for stabilised samples was consistent. However, samples UU_6_200 and ICU 7 400 exhibited different behaviour, whereby their $G_{\max }$ started degrading at lower $\varepsilon_{\mathrm{q}}$ of 0.36 and $0 \cdot 1 \%$, respectively. Due to the early onset of $G_{\max }$ degradation for these samples, they reached residual $G$ at lower $\varepsilon_{\mathrm{q}}(0 \cdot 75 \%$ for UU_6_200, 1.7\% for ICU_7_400) compared with other samples. This was attributed to the development and propagation of micro-cracks, which may be a result of variability in sample mixing quality.

\section{Mineralogical and microstructural features Mineralogy.}

Untreated alluvium. XRD results for the untreated alluvium are presented in Fig. 3, whereby quartz (Q) was the most dominant mineral phase due to the soil's high sand and silt contents. Albite (Na) and orthoclase (K) feldspars of igneous origin were detected, alongside dolomite (D), chlorite (C) and multiple clay minerals including illite (I), vermiculite (V) and smectite (M).

GGBS-sodium hydroxide-treated alluvium. Similar to the untreated alluvium, XRD spectra for the $28 \mathrm{~d}$ stabilised alluvium (Fig. 4) show that quartz was the dominant mineral phase. While XRD was unable to detect cementitious gels (e.g. $\mathrm{C}-\mathrm{S}-\mathrm{H}, \mathrm{C}-\mathrm{A}-\mathrm{H}$ ), there are numerous compositional differences in the stabilised alluvium compared with the untreated soil; whereby chlorite, smectite and dolomite minerals could not be detected. It is likely that the calcium 


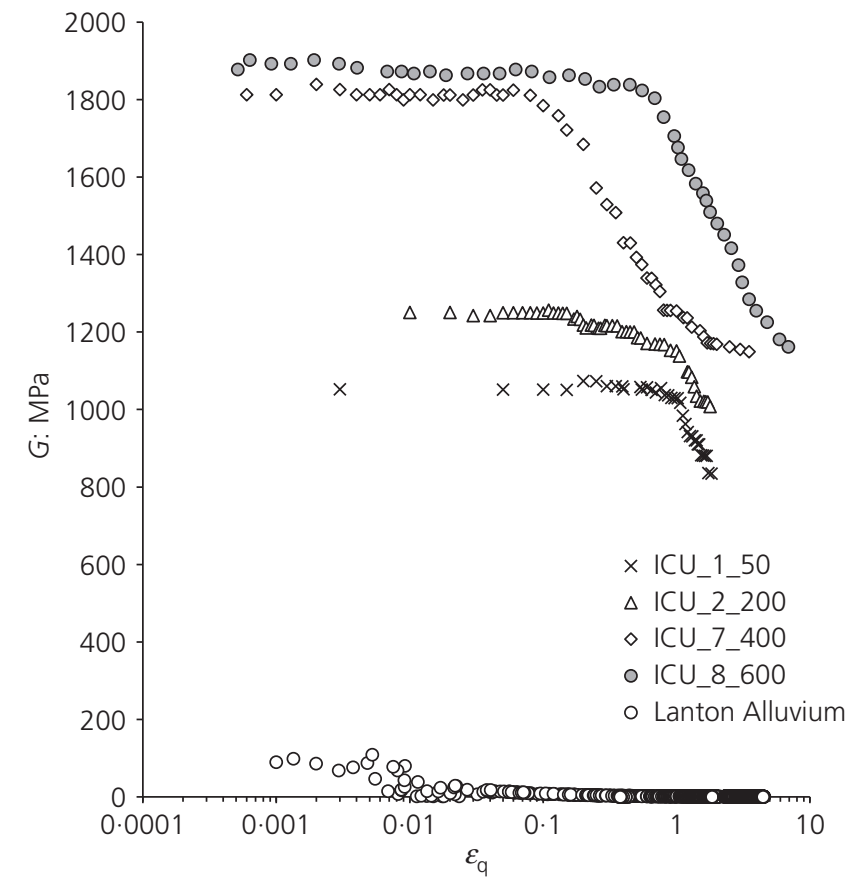

(a)

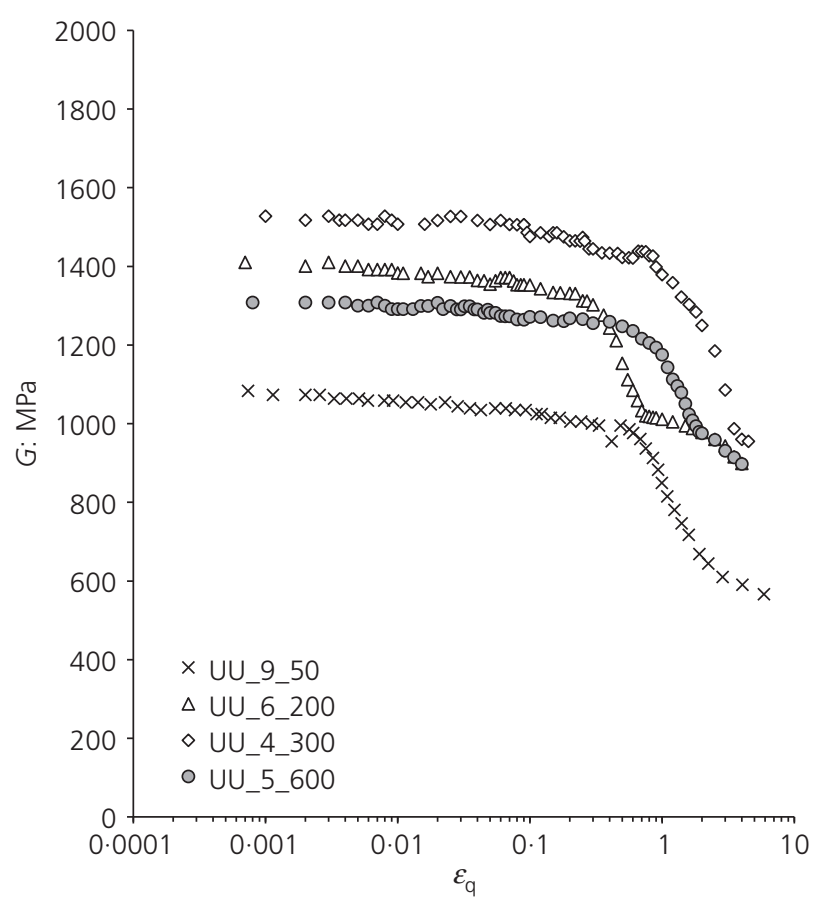

(b)

Fig. 2. Small-strain $\mathrm{G}$ degradation curves for untreated and $28 \mathrm{~d}$ cured Lanton alluvium stabilised with $7 \cdot 5 \%$ GGBS-sodium hydroxide under (a) ICU and (b) UU triaxial testing conditions

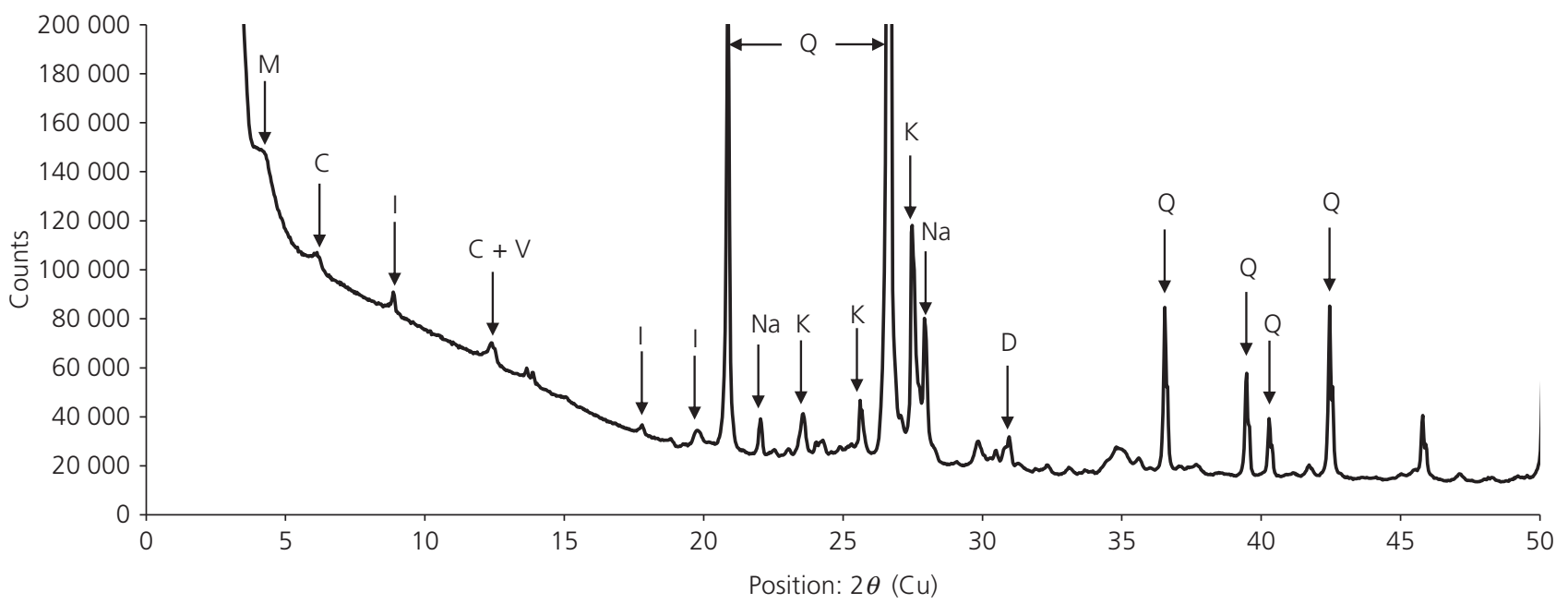

Fig. 3. XRD spectra for untreated Lanton alluvium (includes ICDD interpretation)

content of dolomite, the silica and alumina content of chlorite minerals were utilised during hydration and pozzolanic reactions to form new cementitious gels. The peak intensity for clay minerals within the stabilised alluvium are lower than for the untreated alluvium, indicating that they had partially converted into cementitious gels.

\section{Microstructure.}

Untreated alluvium. The SEM micrograph presented in Fig. 5 shows the presence of fine-grained sub-angular sand and silt (quartz) particles, which form inter-particle edge-to-edge and edge-to-face contacts. Illite platelets are widely distributed throughout the soil, occupying pore spaces between silt and sand grains. Smaller chlorite platelets $(<10 \mu \mathrm{m})$ partially coat surfaces of some larger sand and silt grains. The surfaces of individual particles were clean with no evidence of inter-particle bonding.

EDX spectra (from Fig. 5(a)) are presented in Fig. 6, with the corresponding quantitative elemental composition presented in Table 2. The dominant elemental peaks for silica and oxygen correspond to the soil's high quartz (silt/sand) content. The high potassium and aluminium peaks correspond to the orthoclase feldspar and illite content. The low magnesium content relates to the vermiculite and illite minerals, whereas the calcium peak can be attributed to albite feldspar and the peak for iron is linked with the soil's chlorite content. 


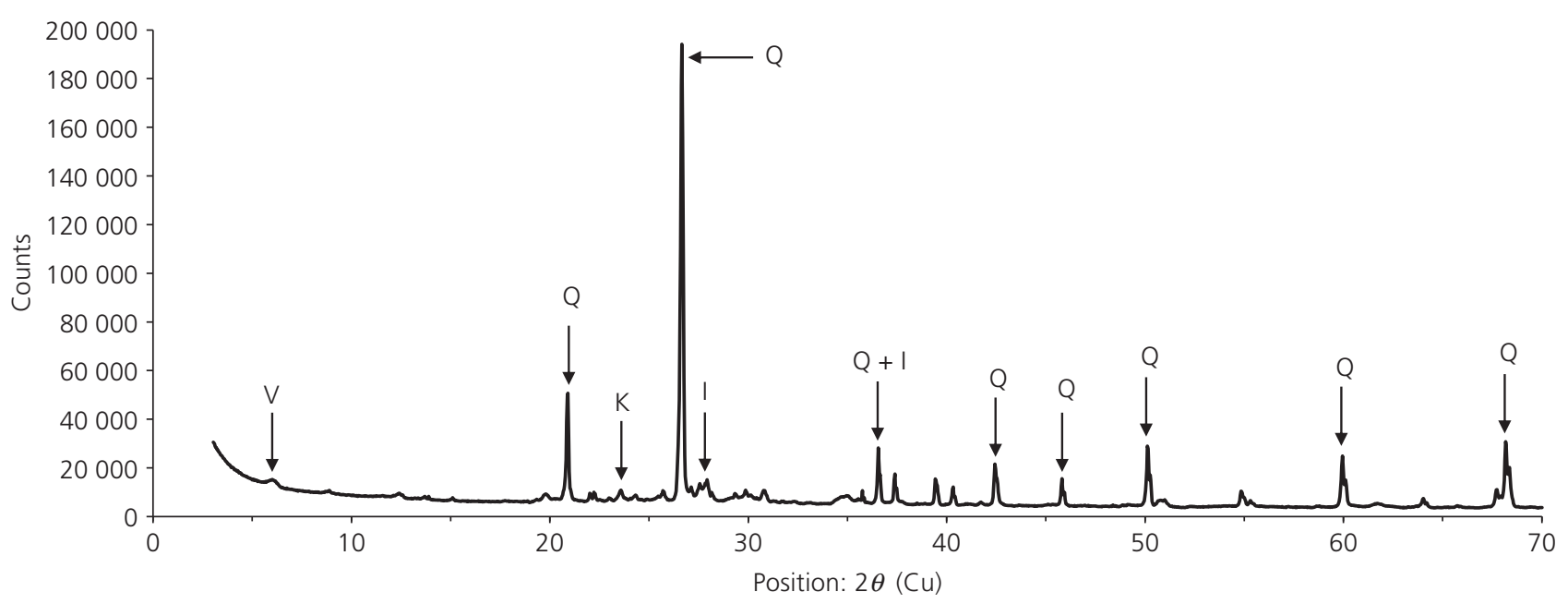

Fig. 4. XRD spectra 7.5\% GGBS-sodium hydroxide-treated Lanton alluvium after $28 \mathrm{~d}$ curing

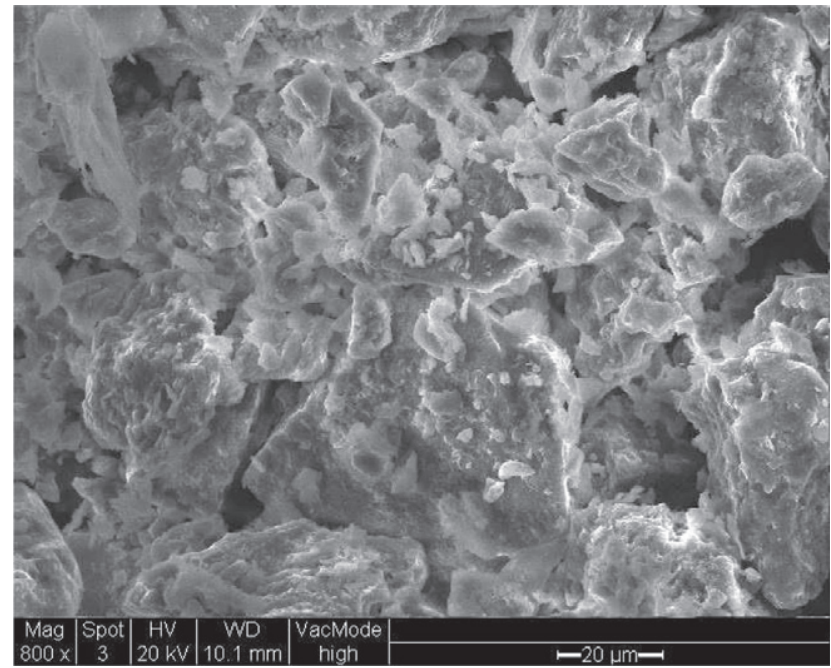

(a)

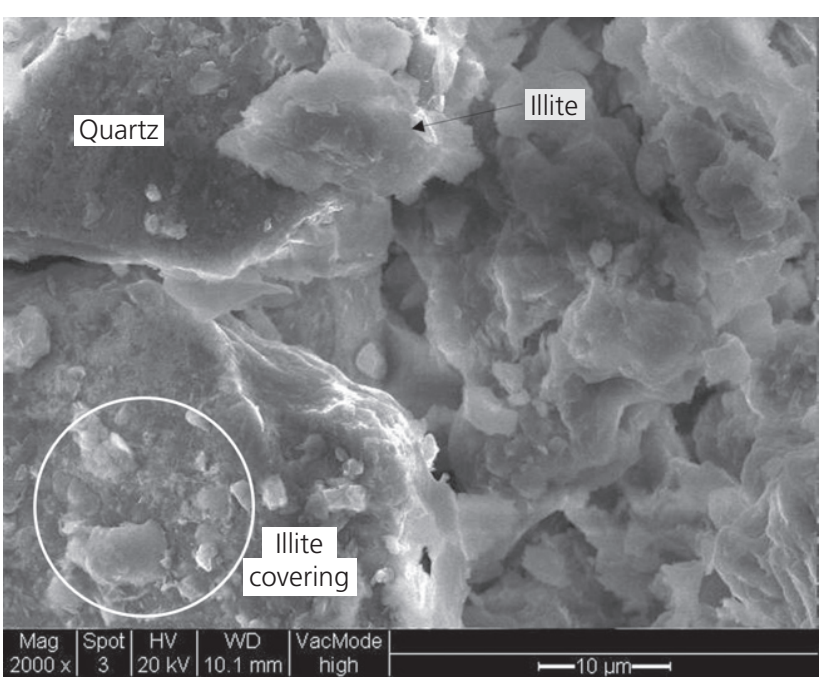

(b)

Fig. 5. SEM micrographs of untreated Lanton alluvium at magnifications of: (a) $\times 800$ and (b) $\times 2000$

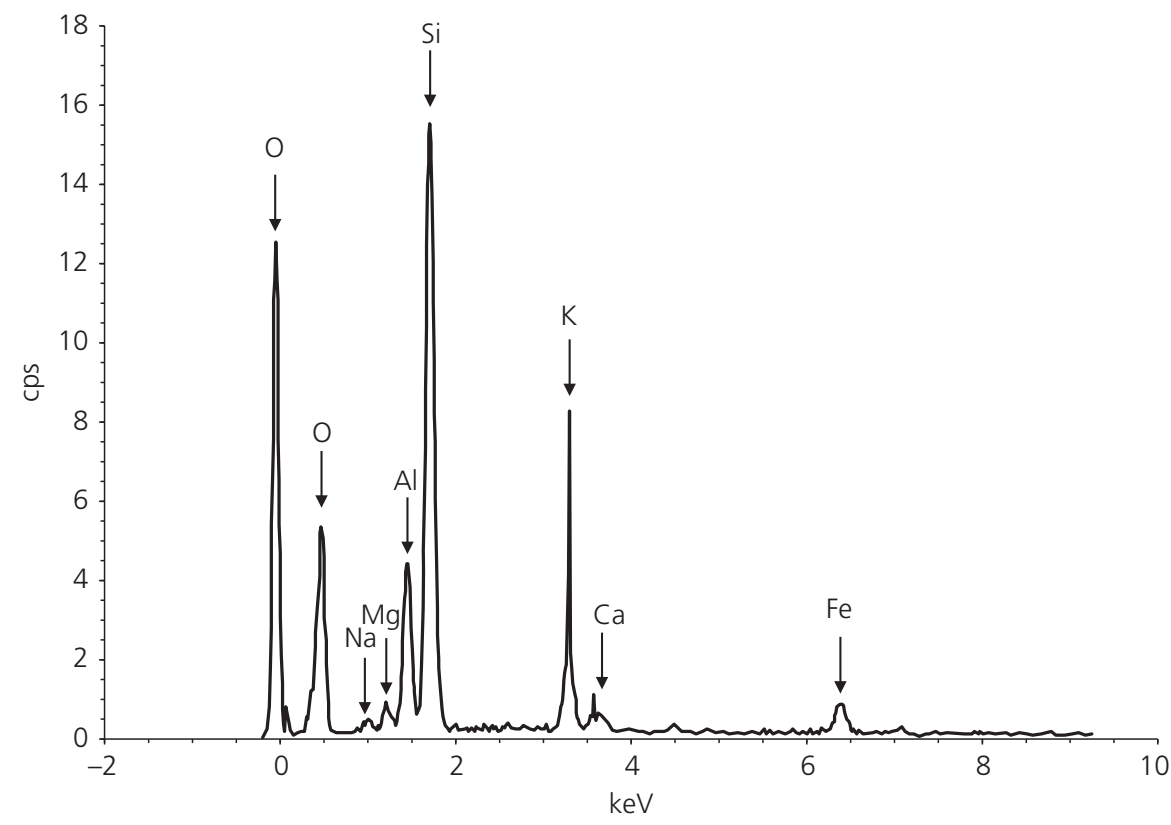

Fig. 6. EDX spectra for Lanton alluvium 
GGBS-sodium hydroxide-treated alluvium. Particle morphologies within the treated alluvium (Fig. 7(a)) were more complex compared with the untreated alluvium, due to the inclusion of GGBS and new cementitious growth. GGBS particles were glassy, highly angular and largely $<20 \mu \mathrm{m}$, which is attributed to ground granulation in ball mills (Wan et al., 2004). EDX spectra for the GGBS are shown in Fig. 8. While GGBS composition varies between iron/steel manufacture plants, the composition of that used in this study is comparable with most GGBS powders with high concentrations of silica, calcium and aluminium, low concentrations of magnesium (Scott et al., 1986).

Pore space apertures within the stabilised alluvium were notably smaller compared with the untreated alluvium due to infilling with new cementitious growth, as seen in Fig. 7(a). Soil and sodium hydroxide-activated GGBS particles exhibited face-to-face, edge-to-edge and edgeto-face contacts. This modified microstructure explains the reduced permeability and higher strength of the stabilised alluvium compared with the untreated counterpart.

Features of interest within the material were lightcoloured amorphous growth coating sodium hydroxideactivated GGBS particles and bonding them with soil particles, as seen in Fig. 7(b). A significant proportion of amorphous surface coatings were likely to be C-S-H gels; whereby darker inner zones formed during later stages of hydration and lighter outer zones formed during the first few days of hydration (Haha et al., 2011).

EDX spectra for the stabilised alluvium are presented in Fig. 9, with the accompanying data in Table 2. The corresponding spectra and data for the amorphous growth in Fig. 7(b) (point '0') are presented in Fig. 10 and Table 3, respectively. While the composition of the alluvium in its untreated and stabilised states were relatively similar, there were some notable differences in Fig. 9 attributable to the GGBS-sodium hydroxide binder and subsequent cementitious reactions. These included larger peaks for sodium, calcium and sulfur.

The EDX results presented in Fig. 10 and Table 3 for point ' 0 ' in Fig. 7(b) indicate that the amorphous cementitious growth has high concentrations of silica, aluminium, oxygen and slightly lower concentrations of calcium, sodium, magnesium and iron. This suggests it is likely to be $\mathrm{C}-(\mathrm{N})-\mathrm{A}-\mathrm{H}, \mathrm{C}-(\mathrm{N})-\mathrm{S}-\mathrm{H}$ or $\mathrm{C}-(\mathrm{N})-\mathrm{A}-\mathrm{S}-\mathrm{H}$. The magnesium and iron peaks are likely to be derived from vermiculite and/or chlorite, which have either been partially or entirely converted into cementitious gels. The point elemental EDX spectra for point ' 1 ' in Fig. 7(b) were

Table 2. Quantitative elemental composition of Lanton alluvium, GGBS and $28 \mathrm{~d}$ cured Lanton $+7 \cdot 5 \%$ GGBS-sodium hydroxide from EDX spectra analysis

\begin{tabular}{|c|c|c|c|c|c|c|c|}
\hline \multirow[t]{2}{*}{ Element } & \multirow[t]{2}{*}{ Series } & \multicolumn{2}{|c|}{ Lanton alluvium } & \multicolumn{2}{|r|}{ GGBS } & \multicolumn{2}{|c|}{$\begin{array}{c}28 \mathrm{~d} \text { Lanton }+7 \cdot 5 \% \\
\text { GGBS-sodium hydroxide }\end{array}$} \\
\hline & & Net & $\begin{array}{c}\text { Normally } \\
\text { consolidated: } \mathrm{wt} \%\end{array}$ & Net & $\begin{array}{c}\text { Normally } \\
\text { consolidated: } \mathrm{wt} \%\end{array}$ & Net & $\begin{array}{c}\text { Normally } \\
\text { consolidated: } \mathrm{wt} \%\end{array}$ \\
\hline $\begin{array}{l}\text { Silicon } \\
\text { Aluminium } \\
\text { Potassium } \\
\text { Calcium } \\
\text { Sodium } \\
\text { Iron } \\
\text { Titanium } \\
\text { Sulfur } \\
\text { Oxygen } \\
\text { Magnesium } \\
\text { Total: }\end{array}$ & $\begin{array}{l}\mathrm{K} \\
\mathrm{K} \\
\mathrm{K} \\
\mathrm{K} \\
\mathrm{K} \\
\mathrm{K} \\
\mathrm{K} \\
\mathrm{K} \\
\mathrm{K} \\
\mathrm{K}\end{array}$ & $\begin{array}{r}17436 \\
4651 \\
2888 \\
424 \\
186 \\
1314 \\
282 \\
1 \\
2245 \\
418\end{array}$ & $\begin{array}{c}31 \cdot 41 \\
8 \cdot 39 \\
5 \cdot 95 \\
0 \cdot 92 \\
1 \cdot 39 \\
5 \cdot 38 \\
0 \cdot 75 \\
0 \\
44 \cdot 91 \\
0 \cdot 91 \\
100\end{array}$ & $\begin{array}{r}10695 \\
3582 \\
703 \\
20456 \\
210 \\
183 \\
213 \\
593 \\
1220 \\
1895\end{array}$ & $\begin{array}{r}16 \cdot 53 \\
5 \cdot 99 \\
1 \cdot 09 \\
36 \cdot 73 \\
1.52 \\
0 \cdot 68 \\
0 \cdot 55 \\
0 \cdot 99 \\
32 \cdot 30 \\
3 \cdot 72 \\
100\end{array}$ & $\begin{array}{r}13614 \\
3577 \\
1791 \\
1024 \\
178 \\
758 \\
156 \\
1 \\
3998 \\
367\end{array}$ & $\begin{array}{c}20 \cdot 28 \\
5 \cdot 66 \\
3 \cdot 01 \\
1 \cdot 80 \\
1 \cdot 44 \\
2 \cdot 96 \\
0 \cdot 34 \\
0 \\
63 \cdot 78 \\
0 \cdot 72 \\
100\end{array}$ \\
\hline
\end{tabular}

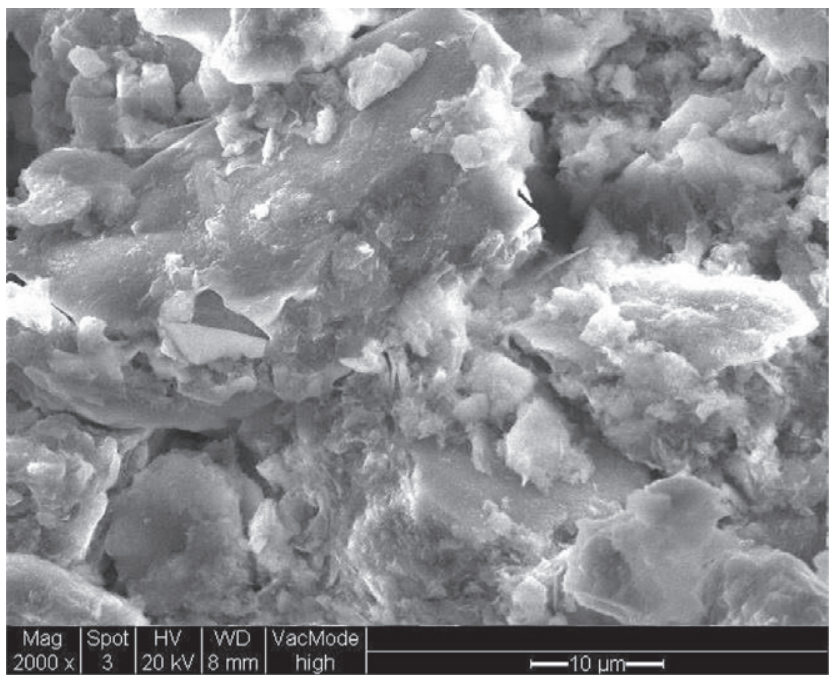

(a)

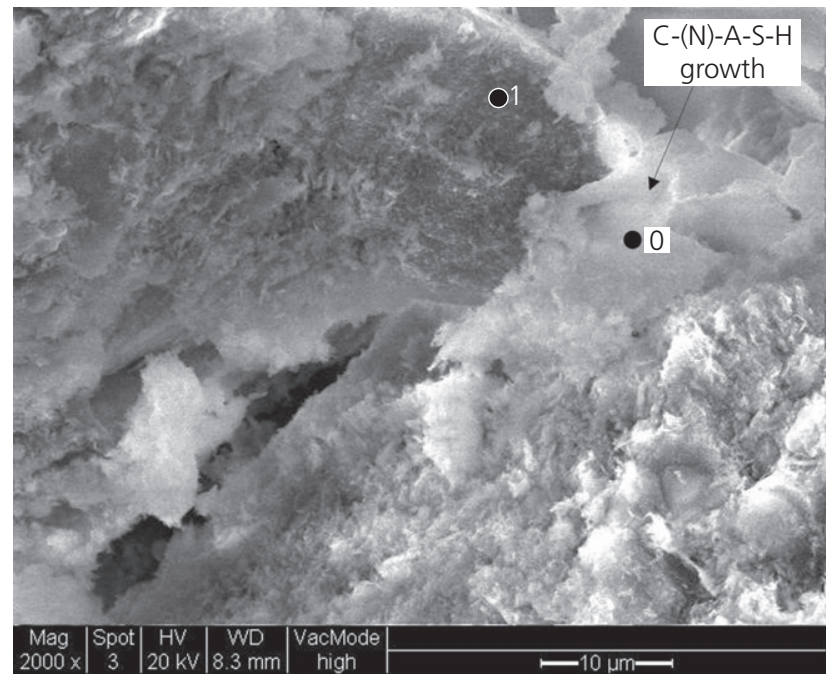

(b)

Fig. 7. SEM micrographs of $28 \mathrm{~d}$ cured GGBS-sodium hydroxide-treated Lanton alluvium at $\times 2000$ magnification: (a) small-scale cementitious gel growths and (b) large-scale cementitious gel growths (with locations selected for point elemental EDX analyses) 


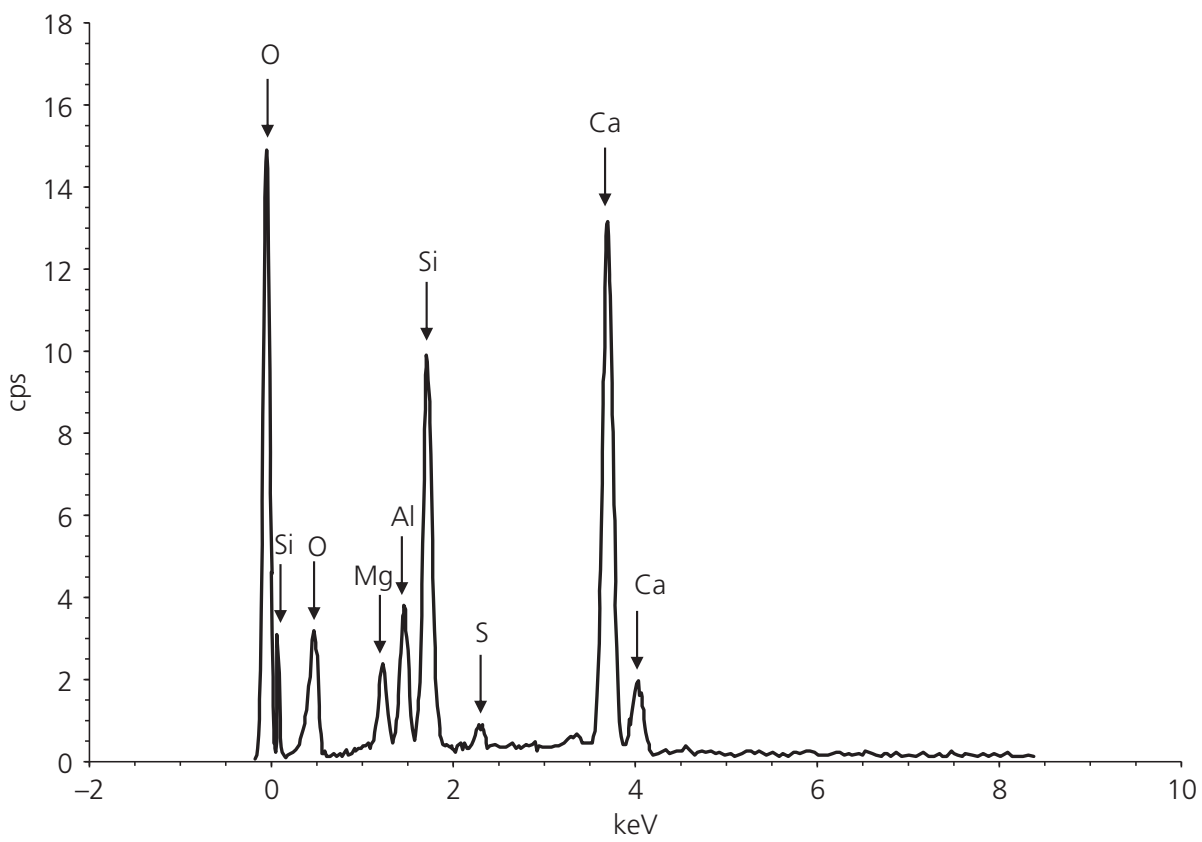

Fig. 8. EDX spectra for GGBS

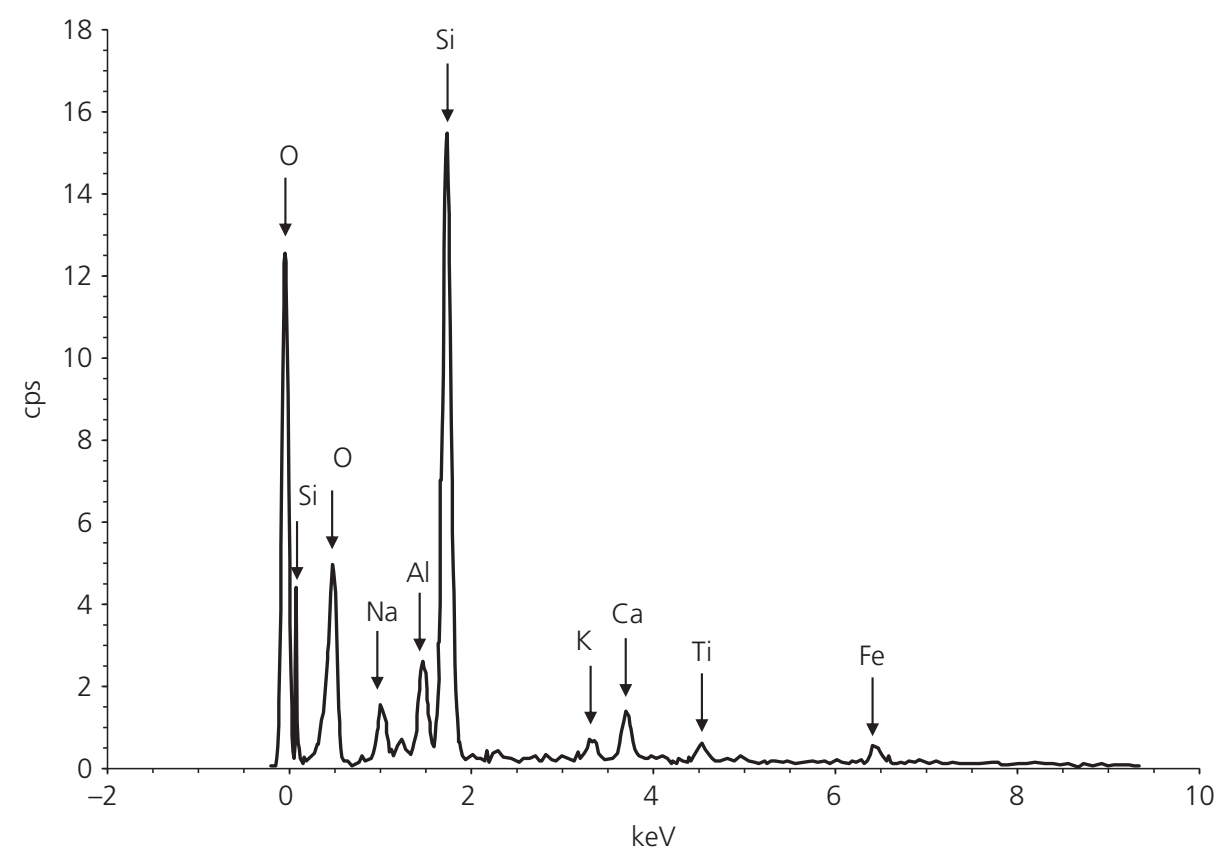

Fig. 9. EDX spectra for 28 d cured GGBS-sodium hydroxide-treated Lanton alluvium (green) compared with spectra for the Lanton alluvium (blue) (based on field of view in Fig. 7(a))

characterised by strong peaks for silica and oxygen, implying the particle was quartz.

No structurally unfavourable Aft minerals were detected within the treated alluvium. Due to the alluvium's low sulfate content (Sargent et al., 2016), this corroborates with Nair \& Little (2009), who stated that high moisture and sulfate contents are required for ettringite formation. Furthermore, ettringite was not expected based on hydration kinetics (Haha et al., 2011).

\section{CONCLUSIONS AND RECOMMENDATIONS}

Over recent years, there has been heightened interest in the small-to-large strain mechanical behaviour of soft soils stabilised with low carbon binders. This paper has built on this existing body of knowledge by providing insights into the mineralogical and microstructural characteristics of such materials and their influence on mechanical behaviour at the macro scale. An alluvium was stabilised with GGBS-sodium hydroxide at a dosage of $7 \cdot 5 \%$, which increased $G_{\max }$ by up to 20 times reaching values of up to $\sim 1800 \mathrm{MPa}$ after $28 \mathrm{~d}$ curing. This treatment also significantly increased the $\varepsilon_{\mathrm{q}}$ at which $G_{\max }$ started to degrade compared with the untreated soil. XRD analyses indicated that the alluvium experienced mineralogical modifications on stabilisation with GGBS-sodium hydroxide and $28 \mathrm{~d}$ of curing. One of the most pertinent changes observed was that some of the clay minerals within the original soil were 


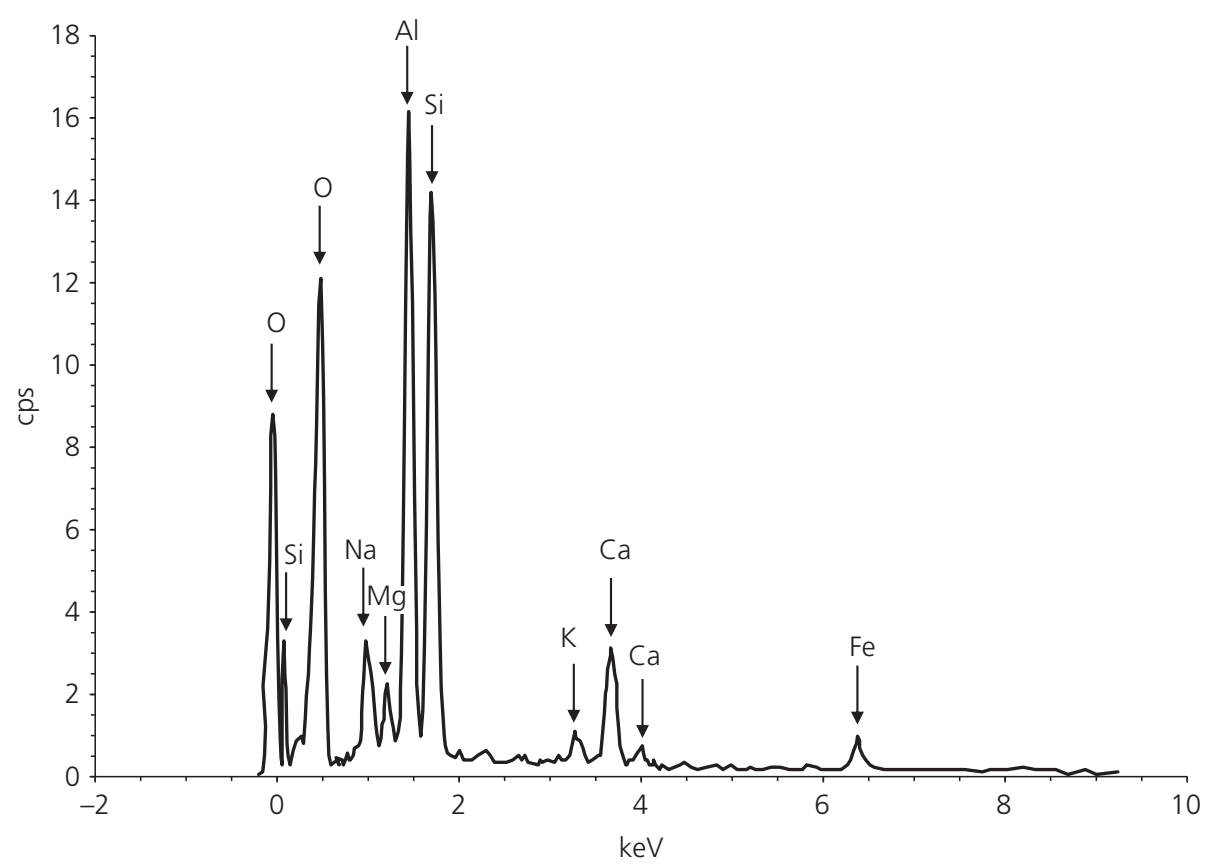

Fig. 10. Point elemental EDX analysis for point '0' shown in Fig. 7(b)

Table 3. Quantitative elemental composition for point '0' shown in Fig. 7(b) from EDX spectra analysis presented in Fig. 10

\begin{tabular}{l|l|r|c}
\hline Element & Series & \multicolumn{1}{|c|}{ Net } & Normally consolidated: wt $\%$ \\
\hline Silicon & $\mathrm{K}$ & 17348 & $21 \cdot 49$ \\
Aluminium & $\mathrm{K}$ & 18358 & $19 \cdot 44$ \\
Magnesium & $\mathrm{K}$ & 2148 & $2 \cdot 57$ \\
Sodium & $\mathrm{K}$ & 189 & $0 \cdot 88$ \\
Calcium & $\mathrm{K}$ & 4419 & $5 \cdot 49$ \\
Potassium & $\mathrm{K}$ & 1430 & $1 \cdot 70$ \\
Iron & $\mathrm{K}$ & 958 & $1 \cdot 89$ \\
Oxygen & $\mathrm{K}$ & 10457 & $46 \cdot 54$ \\
Total: & & & 100 \\
\hline
\end{tabular}

partially converted into new amorphous cementitious gels. SEM-EDX analyses indicated that the hydration of GGBS -sodium hydroxide resulted in considerable modifications to the microstructure of the alluvium after $28 \mathrm{~d}$ - specifically increased levels of inter-particle bonding due to the formation of $\mathrm{C}-(\mathrm{N})-\mathrm{A}-\mathrm{H}, \mathrm{C}-(\mathrm{N})-\mathrm{S}-\mathrm{H}$ and/or $\mathrm{C}-(\mathrm{N})-\mathrm{A}-$ $\mathrm{S}-\mathrm{H}$. These gels infilled pore spaces throughout the stabilised soil, accounting for its lower permeability and higher strength.

The results published in this study will assist in making a valuable contribution towards developing a better understanding of cemented soil material behaviour in geotechnical design applications, such as DSM foundations and retaining structures. This would enable more sophisticated numerical modelling of cemented soil-structure interactions to be performed, especially where strain tolerances are small (e.g. retaining walls and tunnels). It is also envisaged that such modelling would make geotechnical designs less conservative compared with current industrial practice, where more simplistic constitutive soil models are typically used to model cemented soil behaviour. Further work is recommended to investigate the porous structure of cemented soil materials and their chemical interactions with adjacent natural soils and steel work.

\section{REFERENCES}

Ahnberg, H. (2007). On yield stresses and the influence of curing stresses on stress paths and strength measured in triaxial testing of stabilized soils. Can. Geotech. J. 44, No. 1, 54-66, https://doi. org/10.1139/T06-096.

Al-Tabbaa, A. \& Evans, C. W. (1998). Pilot in situ auger mixing treatment of a contaminated site - Part 1: treatability study. Proc. Inst. Civil Engrs, Geotech. Engng 13, No. 1, 52-59, https://doi. org/10.1680/igeng.1998.30005.

Bonal, J., Donohue, S. \& McNally, C. (2012). Wavelet analysis of bender element signals. Géotechnique 62, No. 3, 243-252, https://doi.org/10.1680/geot.9.P.052.

BSI (1990). BS 1377: Incorporating amendment no. 1, methods of test for soils for civil engineering purposes. London, UK: BSI.

Cai, Y., Dong, Q., Wang, J., Gu, C. \& Xu, C. (2015). Measurement of small strain shear modulus of clean and natural sands in saturated condition using bender element test. Soil Dyn. Earthq. Engng 76, 100-110, https://doi.org/10.1016/j.soildyn.2014.12. 013.

Cristelo, N., Glendinning, S., Fernandes, L. \& Pinto, A. T. (2013). Effects of alkaline-activated fly ash and Portland cement on soft soil stabilisation. Acta Geotech. 8, No. 4, 395-405, https://doi. org/10.1007/s11440-012-0200-9.

Consoli, N. C., Viana da Fonseca, A., Cruz, R. C. \& Heineck, K. S. (2009). Fundamental parameters for the stiffness and strength control of artificially cemented sand. J. Geotech. Geoenviron. Engng 135, No. 9, 1347-1353, https:/doi.org/10.1061/_ASCE_ GT.1943-5606.0000008.

Cuccovillo, T. \& Coop, M. R. (1997). Yielding and pre-failure deformation of structured sands. Géotechnique 47, No. 3, 491-508, https://doi.org/10.1680/geot.1997.47.3.491.

Dvorkin, J., Mavko, G. \& Nur, A. (1991). The effect of cementation on the elastic properties of granular material. Mech. Mater. 12, No. 3-4, 207-217.

Ghadir, P. \& Ranjbar, N. (2018). Clayey soil stabilization using geopolymer and Portland cement. Constr. Build. Mater. 188, 361-371.

Haha, M. B., Le Saout, G., Winnefeld, F. \& Lothenbach, B. (2011). Influence of activator type on hydration kinetics, hydrate assemblage and microstructural development of alkali activated blast-furnace slags. Cem. Concr. Res. 41, No. 3, 301-310, https://doi.org/10.1016/j.cemconres.2010.11.016.

Hancock, M. (2019). Soil mixing foundation used as an alternative to piles. Ground Engng Mag. See https://www.geplus.co. 
uk/news/soil-mixing-foundation-used-as-an-alternative-to-piles12-10-2018/ (last accessed 23/05/2019).

Hird, C. \& Chan, C. (2008). One-dimensional compression tests on stabilized clays incorporating shear wave velocity measurements. Geotech. Test. J. 31, No. 2, 166-174.

Horpibulsuk, S., Rachan, R., Chinkulkijniwat, A., Raksachon, Y. \& Suddeepong, A. (2010). Analysis of strength development in cement-stabilized silty clay from microstructural considerations. Constr. Build. Mater. 24, No. 10, 2011-2021, https://doi.org/10. 1016/j.conbuildmat.2010.03.011.

ICDD (International Centre for Diffraction Data) (1999). The powder diffraction file: database of the International Centre for Diffraction Data, sets 1-49. Newtown Square, PA, USA: ICDD.

Kang, G., Tsuchida, T. \& Kim, Y. (2017). Strength and stiffness of cement-treated marine dredged clay at various curing stages. Constr. Build. Mater. 132, 71-84, https://doi.org/10.1016/j.conbuildmat.2016.11.124.

Mohammadinia, A., Disfani, M. M., Conomy, D., Arulrajah, A., Horpibulsuk, S. \& Darmawan, S. (2019). Utilization of alkali-activated fly ash for construction of deep mixed columns in loose sands. J. Mater. Civ. Engng 31, No. 10, 04019233, https://doi.org/10.1061/(ASCE)MT.1943-5533. 0002878 .

Nair, S. \& Little, D. N. (2009). Water as the key to expansion of ettringite in cementitious materials. Transp. Res. Rec. 2104, 55-62, https://doi.org/10.3141/2104-06.

Pourakbar, S., Asadi, A., Huat, B. \& Fasihnikoutalab, M. H. (2015). Soil stabilisation with alkali-activated agro-waste. Environ. Geotech. 2, No. EG6, 359-370.

Rios, S., Viana da Fonseca, A. \& Baudet, B. A. (2014). On the shearing behaviour of an artificially cemented soil. Acta Geotech. 9, 215-226, https://doi.org/10.1007/s11440-013-0242-7.
Rios, S., Cristelo, N., Viana da Fonseca, A. \& Ferreira, C. (2017). Stiffness behaviour of soil stabilized with alkali-activated fly ash from small to large strains. Int. J. Geomech. 17, No. 3, 04016087 , https://doi.org/10.1061/(ASCE)GM.1943-5622.0000783.

Sargent, P. (2015). Secondary minerals to replace cement in stabilising an alluvium. $\mathrm{PhD}$ thesis, Newcastle University, Newcastle upon Tyne, UK.

Sargent, P., Hughes, P. N., Rouainia, M. \& White, M. L. (2013). The use of alkaline activated waste binders in enhancing the mechanical properties and durability of soft alluvial soils. Engng Geol. 152, No. 1, 96-108.

Sargent, P., Hughes, P. N. \& Rouainia, M. (2016). A new low carbon cementitious binder for stabilising weak ground conditions through deep soil mixing. Soils Found. (Jpn. Geotech. Soc.). 56, No. 6, 1021-1034, https://doi.org/10.1016/j.sandf.2016.11.007.

Scott, P. W., Critchley, S. R. \& Wilkinson, F. C. F. (1986). The chemistry and mineralogy of some granulated and pellitized blastfurnace slags. Mineral. Mag. 50, No. 355, 141-147, https:// doi.org/10.1180/minmag.1986.050.355.19.

Trhlikova, J., Masin, D. \& Bohac, J. (2012). Small-strain behaviour of cemented soils. Géotechnique 62, No. 10, 943-947, https://doi. org/10.1680/geot.9.P.100.

Wan, H., Shui, Z. \& Lin, Z. (2004). Analysis of geometric characteristics of GGBS particles and their influences on cement properties. Cem. Concr. Res. 34, No. 1, 133-137, https://doi.org/10.1016/S0008-8846(03)00252-7.

Yun, T. S. \& Santamarina, J. C. (2005). Decementation, softening and collapse: changes in small-strain shear stiffness in $k_{0}$ loading. J. Geotech. Geoenviron. Engng 131, No. 3, 350-358.

Zhu, F., Li, Z., Dong, W. \& Ou, Y. (2019). Geotechnical properties and microstructure of lime-stabilized silt clay. Bull. Engng Geol. Environ. 78, No. 4, 2345-2354, https://doi.org/10. 1007/s10064-018-1307-5. 